\title{
O CONCEITO DE CURA DA TUBERCULOSE PULMONAR (*)
}

\author{
DR. JULIO DE GOUVEIA
}

A ideia de cura implica imediatamente nas ideias de saúde e doença; quais os significados exatos destas palavras? Ninguem ignora as dificuldades que se apresentam ao tentar definí-las com exatidão, príncipalmente por envolverem tambem as questões de normalidade e anormalidade. Quaisquer definições que śe procure dar de normal e anormal, de saúde e doença, ou de vida e de morte, são passíveis das maiores críticas, pois tais feñômenos são por demais complexos para caberem numa única fórmula rígida, sem falar no conhecimento imperfeito que deles ainda temos.

Portanto, sem pretenđer definições, lembraremos apenas que vida e saúde são estados de equilibrio dependentes de fatôres orgânicos internos mais ou menos desconhecidos, e de fatôres externos de natureza vária; o rompimento desse equilibrio (variável aliás com condições de raça, idade, sexo, ou mesmo condições individuais), resulta nas doenças, e, quando mais pronunciado o rompimento, sobrevem a morte.

O estado de saude é caracterizado pelo funcionamento silencioso de todos as orgãos, aparelhos e sistemas da economia, e por uma sensação mais ou menos inconsciente de bem estar físico e moral.

O conceito de moléstia está intimamente ligado à ideia de reações orgânicas, frente ao ataque dos múltiplos fatôrès patogênicos, internos ou externos, e desnecessário será frizar a importância quasi igual que se atribúe modernamente a ambos fatôres, patogênico e defensivo, no rompimento do equilíbrio vital e desencadeamento da moléstia.

Esta, uma vez instalada, determina alterações ou perturbações de ordem anatômica, funcional e imunobiológica que, na maioria dos casos, sóem ser de caráter permanente, mesmo após a terminação dà doença.

Cabe aqui, então; a pergunta: Como se termina a doença?

Si é difícil estabelecer os significados de saúde e doença, mais difícil, si não impossível, será dizer com precisão quando se iniciam as primeiras alterações patológicas - e, mais ainda, estabelecer $o^{\circ}$ momento em que termina a doença e se inicía a cura.

(*) Conferência realisada no Instituto Clemente Ferreira em 29-9-941. 
Cura, em princípio, é o restabelecimento da normalidade e equilíbrio existentes anteriormente à moléstia. Será possível, porém, este restabelecimento?

Absolutamente não, pois as modificações causadas pela doença, ou pelos próprios processos curativos, permanecem sempre, si não em todos; pelo menos em algum ponto do organismo." Envolvendo a moléstia a participação conjunta de fâtôres anatômicos, funcionais, microbianos, imunobiológicos e clínicos, é natural que um conceito amplo de cura deva envolver a restituição conjunta de todos esses fatôres - ocurrência que absolutamente nunca se constata. Não só a irreparabilidade das alterações pode se referir a qualquer um daqueles fatôres, como tạmbem as possíveis restituições não se terminam ao mesmo tempo.

Estes fatos levaram a se considerar diversamente para cada entidade mórbida, o critério de cura: assim, na sífilis, o critério é mais de ordem biológica, enquanto que para a lepra e a malária o critério bacteriológico é soberano, e na pneumonia considera-se mais a restituição anatômica e clínica. Em todas as doenças, porém, impossível é falar em cura, no" sentido amplo, si não existir antes de mais nada uma cura clínica, expressão do restabelecimento daquele equilíbrio característico do estado de saude.

Entretanto, no decorrer de uma moléstia pode se instalar um caráter de cronicidade e estabilidade, com restauração de um novo equilíbrio resultante da adatação do organișmo às novas condições creadas pela doença, equilíbrio geralmente instável, mas que pode, algumas vezes, tornar-se permanente; quando isso acontece, só a observação e a experiência poderão dizer com certeza aproximada si se pode falar em cura ou em simples estabilização.

Pelo que já ficou dito, o conceito atual de cura está limitado, é relativo, e seus elementos variam com cada entidade mórbida considerada. Partindo daí, as moléstias podem ser :

$1^{\circ}$ ) de caráter predominantemente curável

$\left.2^{\circ}\right)$ de caráter predominantemente incurável.

Não é possível fixar com rigidez a curabilidade de uma moléstia, pois mesmo a niais curavel delas pode apresentar casos incuráveis, e vice-versa. Tais a sífilis com suas formas malignas "ab initio", e a peste pneumônica, de cujo surto aqui em São Paulo, ha poucos anos, salvaram-se 2 ou 3 casos.

A qual destes dois grupos pertence a tuberculose?

A feição peculiar que esta entidade mórbida assume, torna a aplicação do conceito de cura particularmente difícil. Com efeito, na tuberculose, mais que em qualquer outro processo patológico, a transição do estado de saúde para o de doença é quasi insensivel, "em virtude da infecção tuberculosa, cujos característicos me abstenho de expôr.

Tuberculose-infecção e tuberculose-doença são duas coisas completamente diversas; ninguem contestará, entretanto, que o organis- 
mo virgem ao tomar contato pela primeira vez com o bacilo tuberculoso, reage de maneira a apresentar todos os característicos anatômicos e clínicos comuns a qualquer moléstia. Esse quadro tão variavel da tuberculose-infecção regride na grande maioria das vezes, e o indivíduo é tido como curado. Houve, porém, uma reștituição completa das condições anteriores?

Parece que não, pois: $10^{\circ}$ ) o test tuberculinico, de negativo tornou-se positivo; $2 .^{\circ}$ ) formaram-se nódulos calcificados pulmonares visíveis na chapa radiográfica e constatáveis na autopsia; $3 .^{\circ}$ ). no interior destes nódulos cảlcificados encontram-se 'frequentemente bacilos vivos capazes de serem cultivados ou inoculados.

Portanto, o critério de cura na tuberculose-infecção é dado apenas pelos componentes clinico, funcional e bacteriológico; anatồmica ou radiologicamente, e biológicamente, a infecção tuḅerculọsa é irreparável.

Para o desencadeamento da tuberculose-moléstia concorrem todos os fatores imaginaveis, endógenos e exógenos; na tuberculose, mais que em qualquer outra entidade mórbida, o bionộmio microbio-organismo é da mais alta consideração; sem bacilo de Koch não ha tuberculose, mas o bacilo pode permanecer indefinidamente no interior de um organismo sem que se deflagre a doença.

Deixando de lado as formas graves de disseminação precoce que se seguem algumas vezes à introdução do bacilo (exemplo notavel, aliás, de insuficiência defensiva), na maioria das vezes o organismo adquire após esse primeiro contato uma capacidade racional específica muito maior, que lhe permite zelar com eficiência pelo novo equilibrio estabelecido.

Não entraremos ná exposição dos motivos endógenos e exógenos responsáveis pela rutura desse equilibrio em tudo semelhante à saude.

Rompido, porém, o equilibrio, instala-se a tuberculose-doença, com todas as alterações anatômicas, funcionais, radiológicas, bacteriológicas e clínicas sobejamente conhecidas; inicia-se então a evolução da moléstia, tão variável, dentro dos aspetos fundamentais que podem ser assumidos: o exudativo e o produtivo. yt:

A experiência tisiológica já demonstrou que o prognóstico das lesões produtivas é mais favoravel que o das formás exudativas; mas este simples diagnóstico qualitativo nada significa isoladamente, enquanto não fôr situado no tempo e relacionado à capacidade reacional do organismo.

Considerada uma evolução favoravel, chega um momento em que, expontaneamente ou após a instituição mais ou menos prolongada de um tratamento médico ou cirúrgico, o individuo doente manifesta claramente o desaparecimento cada vez mais acentuado de todos os sintomas e sinais de sua moléstia.

Chegamos então ao ponto culminante do nosso têma: em que momento pode este tuberculoso pulmonar ser considerado como curado? 
A resposta seria, naturalmente: quando se verificasse o desaparecimento completo de todas as manifestações, subjetivas ou objetivas, que determinaram o diagnóstico em apreço. Já vimos, porém, que o conceito teórico de cura, no sentido amplo e genérico, é uma utopia impossivel de alcançar, e que, para cada doença, deve haver um critério particular baseado na observação e na experimentação.

Qual é esse critério para a tuberculose?

As condições econômicas e sociais do Brasil são tão especiais, que todos, os trabalhos científicos, mormente os que se referirem à tuberculose, deveriam abordar tres questões:

$\left.1 .^{a}\right)$ o problema em geral;

$2 .^{a}$ ) aś experiências alheias;

$\left.3 .^{a}\right)$ as nossas realidades.

Já tivemos ocasião de esvoaçar sobre a primeira destas questões; vejamos, 'pois, o que as experiências alheias nos podem ensinar' sobre o conceito de cura da tuberculose pulmonar.

O Dr. Eduardo Etzel trouxe dos Estados Unidos uma publicação da "National Tuberculosis Association", que é um trabalho de unificação, padronisação e divulgação dos conhecimentos mais modernos sobre tuberculose, para todo o paiz; este trabalho é reeditado cada dois anos, e se caracteriza por aquele cunho prático das coisas americanás. Encontramos aí a seguinte classificação:

1. $\left.{ }^{a}\right)$ Aparentemente curada

2.a) Estabilisada

3. ${ }^{a}$ ) Aparentemente estabilisada

4. ${ }^{a}$ ) Quiescente

$\left.5 .^{\mathrm{a}}\right)$ (Francamente) ativa

( a) melhorada

b) não melhorada

Vejamos o critério desta classificação:

Francamente ativa - Sintomas inalterados, 'mais severos ou menos severos; lesões demonstráveis radiologicamente; escarro quasi sempre contendo bacilo de $\mathrm{KocH}$;

Quiescente - Nenhum sintôma constitucional; lesões radiológicas estacionárias ou em regressão, podendo existir cavidade; o escarro pode ser positivo para KocH; estas condições devem ter existido pelo menos 2 mêses, ambulatoriamente.

Aparentemente estabilisada - Sintômas constitucionais aúsentes; lesões estacionárias e aparentemente curadas à chapa radiográfica; nenhuma evidência de cavidade pulmonar; escarro, si presente, negativo à concentração; estas condições devem ter existido por 3 mêses, sendo os dois últimos com uma hora de caminhada diária, ou seu equivalente. 
Estabilisada - As mesmas condições anteriores durante um periodo de 6 mêses, sendo os dois últimos com uma hora de caminhada duas vezes ao dia, ou seu equivalente.

Aparentemente curada - Sintômas constitucionais ausentes; lesões estacionárias e aparentemente curadas à chapa radiográfica; todas as pesquisas de bacilo de $\mathrm{KocH}$ negativas, inclusive lavagem gástrica, cultura e inoculação;- permanencia desta situação durante 2 anos, sob condições de vida normais.

A publicação da National Tuberculosis Association termina dizendo: "uma percentagem considerável mas ainda não determinada de casos, pode, conservando esta última situação durante seis anos, voltar à vida normal"

V'emos, por um simples exame superficial, que o rigôr dos norteamerịcanos chega ao ponto de, após 2 anos de culturas e inoculações negativas, considerar o doente como apenas "aparentemente curado"; na classificàção da National Tuberculosis Association não entra a palavra "curado". Isso entretanto não significa que os americanos consideram a tuberculose absolutamente incurável, pois concordam em uma volta do indivíduo à vida normal após seis anos de inoculações e culturas constantemente negativas; observe-se porém que, mesmo aqui, não falam eles em "curado"

$\mathrm{Na}$ escola tisiológica espanhola, TÁpIA e RAmón DE CÁstro são de parecer muito semelhante. Para este último, o doente bem tratado,. situado em condições ótimas, passa sucessivamente por tres periodos :

$\left.1 .^{\circ}\right)$ regressão dos sinais exteriores de atividade;

$2^{\circ}$ ) regressão de sinais radiológicos-e clínicos;

$\left.3 .^{\circ}\right)$ redução da imagem radiográfica a elementos cicatriciais de maior ou menor volume, e redução da estridência dos sinais clínicos auscultatórios e percutórios, até certo limite.

Nestas condições o individuo entra em fase de cura aparente; para este autor a cura real é uma utopia: o que se verifica é o que ele chama de cura prática, demonstrável apenas pelo tempo, após reingresso do individuo na vida normal ou semi-normal.

As escolas italiana, francesa e alemã não apresentam unidade de pontos de vista a este respeito, e enquanto uns consideram a tuberculose como a mais curavel das afecçóes cronicas (GRANCHER), outros (BERN HEIM) têm-na como a mais dizimadora e implacável das doenças infecciosas, enquanto Etienne Bernard diz que, de dois tuberculosos pulmonares, dentro de cinco anos um está morto.

A-tendência atual da escola francesa é para considerar cada tuberculoso estabilisado como possuidor de uma determinada capacidade de trabalho, que deve ser aproveitada na medida do possível. Nas industrias de guerra, principalmente, ha uma percentagem cada vez maior de trabalhadores tuberculosos, não só na França, na Italia e na Alemanha, como tambem, mais recentemente, nos Estados Unidos. 
A exigência de cura absoluta vai, cada vez mais, perdendo terreno nesses paizes, e o tuberculoso começa a ser considerado sob outro ponto de vista. Não são conhecidos ainda os resultados dessa atitude, nem os da chamada "terapeutica pelo trabalho" instituida parcialmente em alguns paizes, mas a interpretação dessas medidas parece indicar certo cepticismo na cura integral da tuberculose pulmonar.

Passemos agora às nossas realidades...

O problema da tuberculose no Brasil encontra-se ainda naquele estádio primitivo da iniciativa particular; não ha uma classificação da móléstia, não ha unificação, nem da técnica cirúrgica, nem da colapsoterapia gasósa, nem da indicação terapeutica, nem da interpretação dos elementos fornecidos pelo laboratório, nem ha unificação do conceito de cura. Uma das conclusões do Dr. MAc-Dowéll, relator do I têma do II Congresso Nacional de Tuberculose realizado em São Paulo em maio do corrente ano, foi esta: "necessidade de unificar a técnica e a conduta clínica"; isso, no que se refere ao pneumótórax; 'que dizer então do conceitò de cura?

A tendência mais generalizada dos tisiólogos brasileiros parece ser a de exigir, além de uma radiografia negativa, uma cultura e uma inoculação igualmente négativas, antes de dar alta ao paciente, com o rótulo de curado; predomina o critério radiológico e bacteriológico. Enquanto não se realizarem essas' exigências, o individuo permanecerá cataloggado como doente e, como tal; impossibilitado de trabalhar.

... Naquele mesmo congresso de S. Paulo, "O Dr: Decio DE Queiroz TElies, relator do 2.0 têma, citou a frase dè IckerT: "Só porqu'e elimina bacilos o tuberculoso não é incapaz de trabalhar, mas por causa dos bacilos que elimina, ninguem lhe concede trabalho.". E' a reprodução fotográfica da questão no Brasil.

Um dos colegas, nesta mesma sessão, ha duas semanas, disse que ninguem deveria louvar suas opiniôes científicas em razões de simpatia pessoal; ; creio eu que eșa afirmativa pode e deve ser extendida tambem aos autores estrangeiros, até que se possa comprovar as experiências alheias com trabalhos nacionais.

Cada país tem seus próprios problemas e cada problema tem sua feição propria, diferente da feição do mesmo problema em outro país; cabe aos estudiosos resolver essas questões nacionais, com soluções e recursos nacionais,

No Estado de Michigan, onde esteve o Dr. ETzEL, a tuberculose pulmonar é real e praticamente de notificação obrigatória, e todo doente, mesmo com lesões iniciais minimas, é internado em hospital especializado por seis mêses; mesmo assim, ha 200 leitos vagos por falta de doentes... A National Tuberculosis pode, nessas condições, exigir seis anos de culturas e inoculações repetidamente negativas para permitir o retôrno do individuo à vida normal.

Já na França e ná Alemanha, os tuberculosos estabilisados são aproveitados pelo governo nas industrias de guerra, em ocupação compativel com cada caso individual.

Ha uma capacidade indiscutivel de trabalho, em úm número consideravel de tuberculosos; porque não aproveitá-la? 
Outra conclusão do já citado Congresso foi a seguinte:

"- O tratamento ambulatório, envolvendo o lado social do problema da luta anti-tuberculosa, permite o estudo da forma do aproveitamento da capacidade do paciente para o trabalho, ainda no curso do tratamento".

Isso parece indicar que o assunto será considerado a partir desta data; que assim seja realmente, mas que não se façam leis muito sábias, mas inaplicáveis e inúteis como é a da notificação obrigatória da tuberculose entre nós.

O trabalho, na tuberculose, é um grande fator de agravamento da lesão, mas ninguem ignora que muitas vezes ó agravamento, ou - mesmo uma recaída em doente com alta curado, provem da miseria resultante da falta de trabalho; ninguem quer empregar um individuo que se trata ou que se tratou de tuberculose. A falta de trabatho é, frequentemente, mais prejudicial que o trabalho ele mesmo.

O critério da cura mais corrente entre nós é, como vimos, baseado na limpeza radiológica e ra negatividade bacteriológica da cultura e da inoculação, tidos como decisivos; serão, porém, realmente decisivos, si o que se quer é a garantia absoluta de uma cura indiscutivel : da tuberculose?

A limpeza radiológica é, sem dúvida, aceita com reservas, pois o que se verifica na chapa radiográfica de um individuo curado são as manchas tradutoris de tecido cicatricial, mais ou menos extensas; mas a limpeza radiológica não pode ser confirmada apenas por uma chapa ântero-posterior; como se usa entre nós : a exemplo do que se faz nos Estados ¿Unidos, são necessárias igualmente chapas pósteroanterior, obliqua direita, obliqua esquerda, anteriores e posteriores, e uma ou duas chapas de perfil, sem falar em planigrafias e estereografias.

O. livro de ANDRE MEYER sobre a tuberculose pulmonar oculta com expectoração bacilifera é claro nesse ponto: só com todos estes cuidados se poderia ter a probabilidade dè uma limpeza radiologica, pois ainda haveria uma percentagem, razoavel de lesões inascessíveis aos raios $X$.

No que se refere à esterilisação bacteriológica, o interesse é ainda maior. Aquele mesmo autor demonstrou a existencia indiscutivel de uris poucos casos de baciloscopia positiva temporariamente, em individuos clínica e radiologicamente sấos; traz assim, novamente, à baila, a noção de portadores de germes na tuberculose, à semelhança do que se verifica tó tifo em eutras doençàs infecciosas. MEYER admite, porém, a concomitância de lesõés minimas ocultas, e deixa a questão aberta para melhores verificações.

"Mutátis mutandis", a mesma questã̉o póde se apresentar, não no diàgnóstico inicial, mas quando se investiga bacteriologicamente una cura. Nestas condições, uma pesquisa positiva, quer em exames dè rotina, quer em culturàs e inoculações, não significa obrigatoriamente que o individuo em apreço se encontre ainda doente; ha causas de erro, não só técnicas, como ainda pelos possíveis bacilos paratúberculosos. 
Não ha dúvida que estas causas de erro são evitáveis e despreziveis, mas, imaginemos o caso de serem realmente bacilos tuberculosos. Imaginemos o caso comum de um individuo tratado convenientemente ha varios anos, que se apresenta com sinais radiográficos perfeitamente satisfatórios, nenhum sinal subjetivo ou objetivo de tuberculose, hemossedimentação e todos os exames de rotina normais, inclusive escarro homogeneisado ou conteudo gástrico, e que ha algum tempo vem trabalhando normalmente, com curva ponderal ascendente ou estacionária; nesta situação, qual o valor de uma cultura ou inoculação positiva?

Giuseppe Daddi, da escola italiana, Saenz: e Costil, da escola francesa, concordam com a idéia de expectoração bacilífera em individuos curados. Nem seria possível esperar um milagre; si nos nódulos calcificados do complexo primário existem bacilos vivos, cultivâveis e inoculaveis, como exigir a esterilização de um ex-doente?

Nenhum clínico, e entre eles citariamos Miguel Couto, Annes Dias, Almeida Prado, além dos grandes clínicos estrangeiros, dá modernamente valor absoluto ao laboratório. A este, a parte técnica; ao clínico, a análise dos resultados.

Porque excetuar justamente a tuberculose pulmonar, em que o individuo já é infectado antes de ser doente? A cura não pode ser a morte do germe, pois isso é impossível; porque surpreendermo-nos si ele, desde que existe, aparece em pesquisas de tão alta sensibilidade como a cultura e a inoculação?

A infecção tuberculosa não é doença tuberculosa, nem significa o seu inicio; não ha motivo, pois, para exigir que o fim da doença seja o fim da infecção.

Autores estrangeiros e, entre nós, o Dr. José Rosemberg démonstraram o poder alergisante e patogênico do bacilo de KocH morto, capaz de determinar lesões específicas à distancia, mesmo depois de fragmentado.

Si a concepção moderna dá tuberculose é complexa, o seu conceito de cura não pode ser simplificado e firmado num unico dado de laboratório.

A cura real da tuberculose, naquele sentido de cura que expusemos no início, é inatingível. E uma cura prática, nos moldes de Rist, TÁPIA e RAMón DE CASTRo, depende da interpretação conjunta de todo o quadro da moléstia. i $\mathrm{E}^{\prime}$ necessária uma visão ampla do decorrer clínico do caso, com a comparação de radiografias tiradas em várias épocas, hemossedimentações, verificações do quadro hemático, curva ponderal, e, ao lado de uma interpretação judiciosa das pesquisas bacteriológicas, a observação imprescindível das consequências do trabalho e do retôno progressivo e controlado à vida normal ou sub-normal.

A capacidade de trabalho deve ser sempre considerada, mormente em nosso meio, onde a recuperação do tuberculoso tem tão grande significado econômico; para o proprio doente, a conciência de sua utilidade, ainda que parcial, é de considerável valor psicológico, e o 
perigo de contágio para o meio familiar ou profissional não seria maior que atualmente. ' O tuberculoso que trabalha não só pode manter a familia em padrão mais alto de vida, como fica mais horas afastado de seus proprios filhos, diminuindo assim as probabilidades de contágio para sêres possivelmente predispostos, enquanto que no ambiente profissional, onde prédominam, os individuos adultos, a receptividade é menor.

Querer avaliar a cura de um antigo tuberculoso por uma chapa radiográfica ou por uma pesquisa bacteriológica positiva é coisa que não se pode compreender nem admitir. Dar alta incondicional a qualquer ex-tuberculoso, sem submetê-lo a controle demorado, talvez permanente, é outro absurdo, pois a volta abrupta ao trabalho pode ter consequencias funestas de exacerbação dos fócos latentes.

Nenhuma tuberculose será tida como curável ou incurável, sem a observação de sua projeção no tempo, da capacidade individual de trabalho, e do restabelecimento daquele equilíbrio normal que caracterisa o estado de saúde.

\section{O N C L U S E S}

1. a) Em qualquer doença, infecciosa ou degenerativa, a cura teal, com restituição integral de todas as condições do organismo anteriores à doença, é impossível de se obter;

2. ${ }^{\mathrm{a}}$ ) Para cada moléstia ha um conceito empírico de cura, baseado na observação, variando a predominância dos critérios clínico, anatômico, radiológico, funcional, bacteriológico e imunobiológico;

3. a) Em qualquer moléstia o critério clínico prevalece no conceito de cura, em função do tempo;

4. a) Não é possível obter a esterilisação de um organismo infectado pela tuberculose;

$5 .^{\mathrm{a}}$ ) $\mathrm{O}$ conceito de cura na tuberculose pulmonar deve envolver todo o quadro clínico, radiológico, funcional, imunobiológico e bacteriológico, sob interpretàção conjunta do tisiólogo;

$\left.6 .^{a}\right)$ Não é possível julgar a cura de um ex-tuberculoso por um único dado, seja radiológico, clínico ou bacteriológico;

7. ${ }^{\mathrm{a}}$ Não é possivel julgar a cura de um ex-tuberculoso sem a observação, no tempo, dos efeitos e consequências da volta progressiva e controlada à vida normal ou sub-normal;

8. ${ }^{\mathrm{a}}$ ) Ao dar um tuberculoso como curado, o que se deseja é a restituição maior e mais sólida possível da sua capacidade anterior à moléstia;

9. ${ }^{\text {a }}$ Nenhum tuberculoso pode ser tido como curado incondicionalmente, qualquer que tenha sido o tempo decorrido desde a sua cura aparente;

$\left.10 .^{a}\right) \quad E^{\prime}$ necessário um estudo mais completo e desenvolvido da questão, para unificar, em bases sólidas; o conceito de cura da tuberculose pulmonar. 


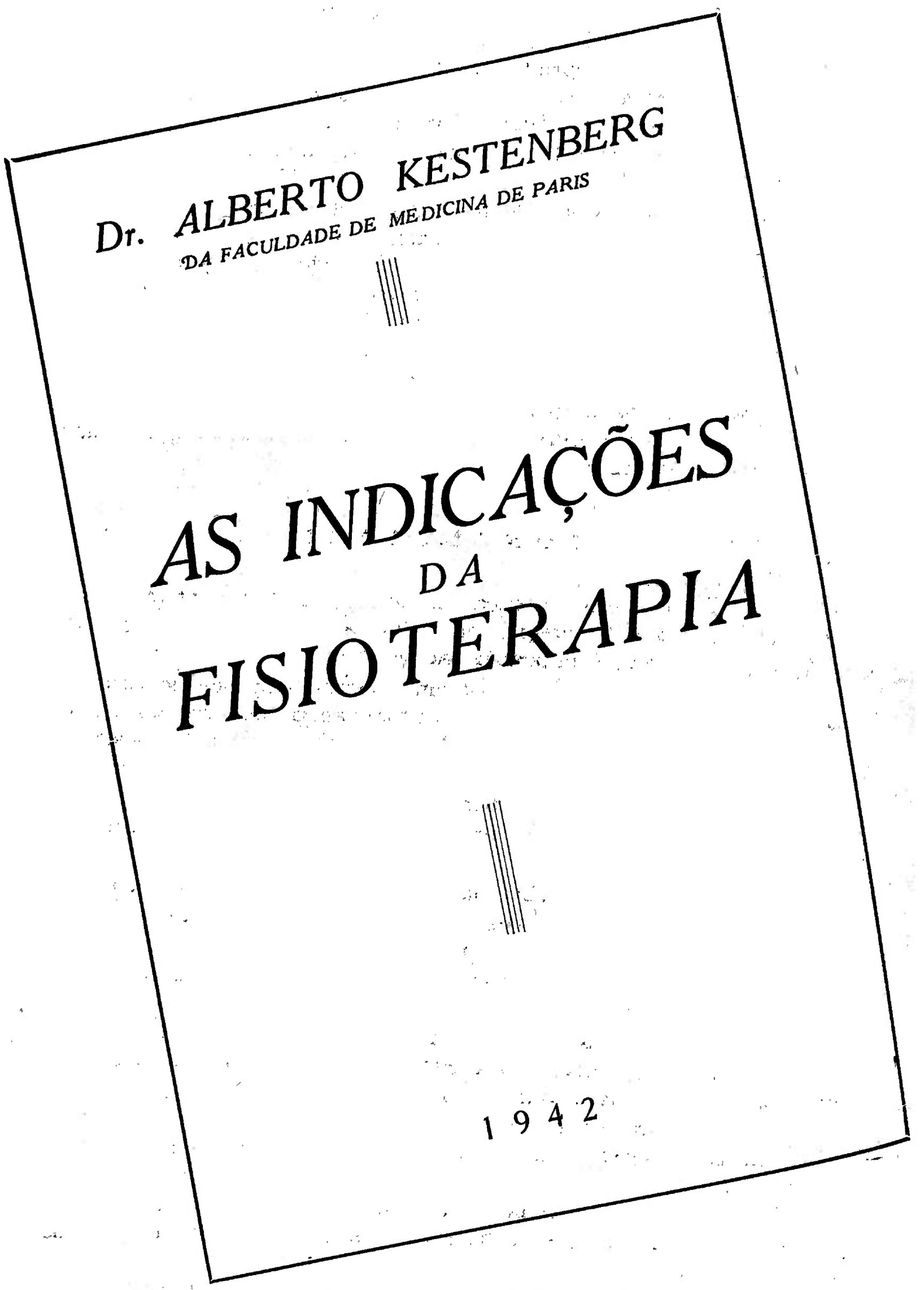

A redação desta Revista terá prazer em enviar aos Snrs. Médicos interessados um exemplar gratis deste memento, de autoria do conhecido cientista Dr. Alberto Kestenberg da Faculdade de Paris. 